Павловська І. Г., докторант Науково-дослідний центр індустріальних проблем розвитку Національної академії наук України м. Харків, Украӥна DOI: https://doi.org/10.30525/978-9934-26-145-9-6

\title{
ФАКТОРИ, ЩО ВПЛИВАЮТЬ НА ЕФЕКТИВНІСТЬ ЛАНЦЮГІВ СТВОРЕННЯ ВАРТОСТІ В ХАРЧОВІЙ ПРОМИСЛОВОСТІ
}

На сучасному етапі розвитку будь-якої держави, харчова промисловість - $\epsilon$ однією з системоутворюючих сфер економіки країни, яка формує як ринок агропродовольчих товарів, так $\mathrm{i}$ 
продовольчу й економічну безпеку, а також харчову незалежність. Особливу роль та значущість харчової промисловості визначає також іiі тісний виробничий та економічний взаємозв'язок 3 майже усіма іншими галузями, зокрема $з$ сільським господарством, промисловістю, транспортом i зв'язком, будівництвом, торгівлею, а також 3 галузями невиробничої сфери (рис. 1) [1].

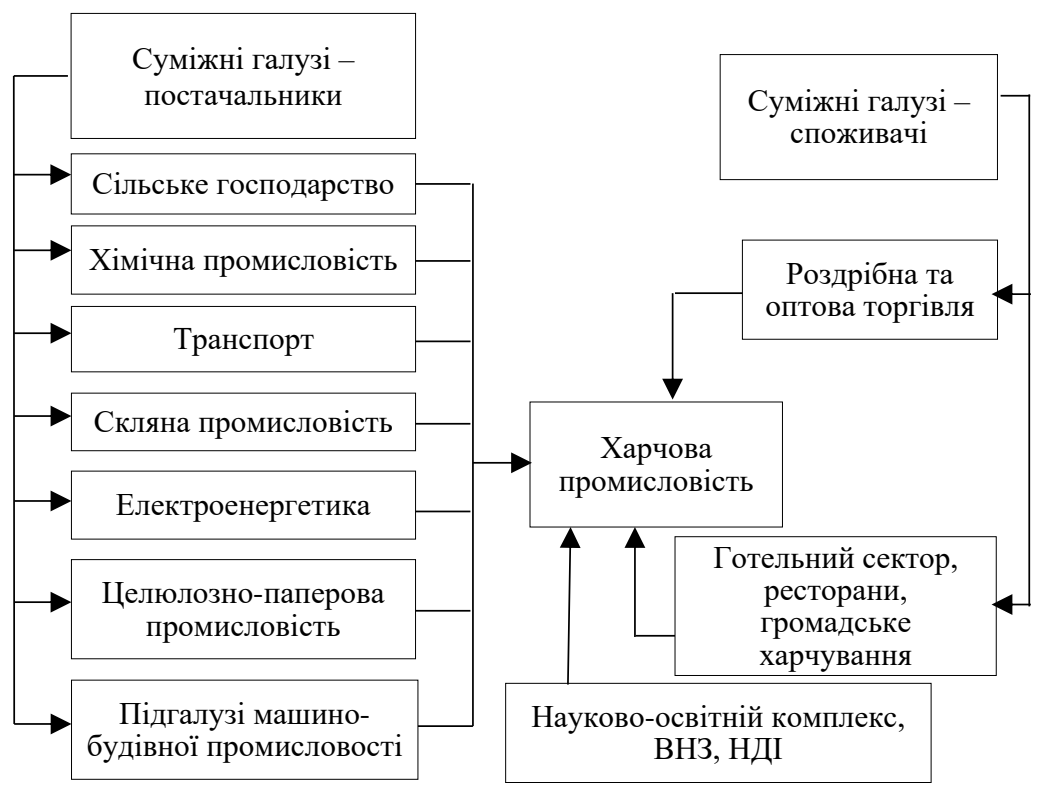

\section{Рис. 1. Взаємозв'язок харчової промисловості та інших галузей економіки}

Слід відмітити, що харчова промисловість в цілому це не одна галузь, а сукупність декількох видів промисловості, що виробляють різноманітний асортимент харчових продуктів. Так, згідно КВЕД-2010 до харчової промисловості відносять [2]: виробництво м'яса та м'ясних продуктів; перероблення та консервування риби, ракоподібних і молюсків; перероблення та консервування фруктів і овочів; виробництво олії та тваринних жирів; виробництво молочних продуктів; виробництво продуктів 
борошномельно-круп'яної промисловості, крохмалив і крохмальних продуктів; виробництво хліба, хлібобулочних і борошняних виробів; виробництво інших харчових продуктів (зокрема, цукру, какао, шоколаду, цукрових кондитерських виробів, чаю, кави, прянощів, приправ, готової їжі та страв, дитячого харчування та дієтичних харчових продуктів тощо); виробництво готових кормів для тварин.

Також слід відзначити, що одні підприємства харчової промисловості (учасники ланцюга створення вартості продуктів харчування) здійснюють первинну переробку сільськогосподарської сировини, до них відносяться підприємства 3 переробки худоби та птиці, 3 вироблення цільномолочної продукції, борошна, крупи, цукрового піску та іншої продукції. Інші підприємства харчової промисловості в основному використовують сировину, що вже пройшла первинну переробку - це хлібозаводи, макаронні та кондитерські фабрики, спиртові та виноробні заводи, підприємства 3 виробництва ковбас та ін., й відносяться до групи підприємств вторинної переробки. Підприємства першої групи, як правило, розміщуються в місцях виробництва сільськогосподарської сировини, а підприємства другої групи тяжіють до сфер споживання вироблюваного ними продукту.

3 поточним розвитком сьогодення до виробництва продуктів харчування пред'являють більш вибагливі та особливі вимоги, головними з яких є: створення високої цінності для споживача, яка виражена в економії часу і зручності придбання, користі для здоров'я і задоволенні різноманітних смакових уподобань; відповідність якості продуктів харчування національним i міжнародним стандартам.

Зміни споживчих переваг покупців призводять до зміщення попиту від простої натуральної продукції до продукції глибокої переробки з більш високою доданою вартістю (рис. 2) [1; 3; 4]. 


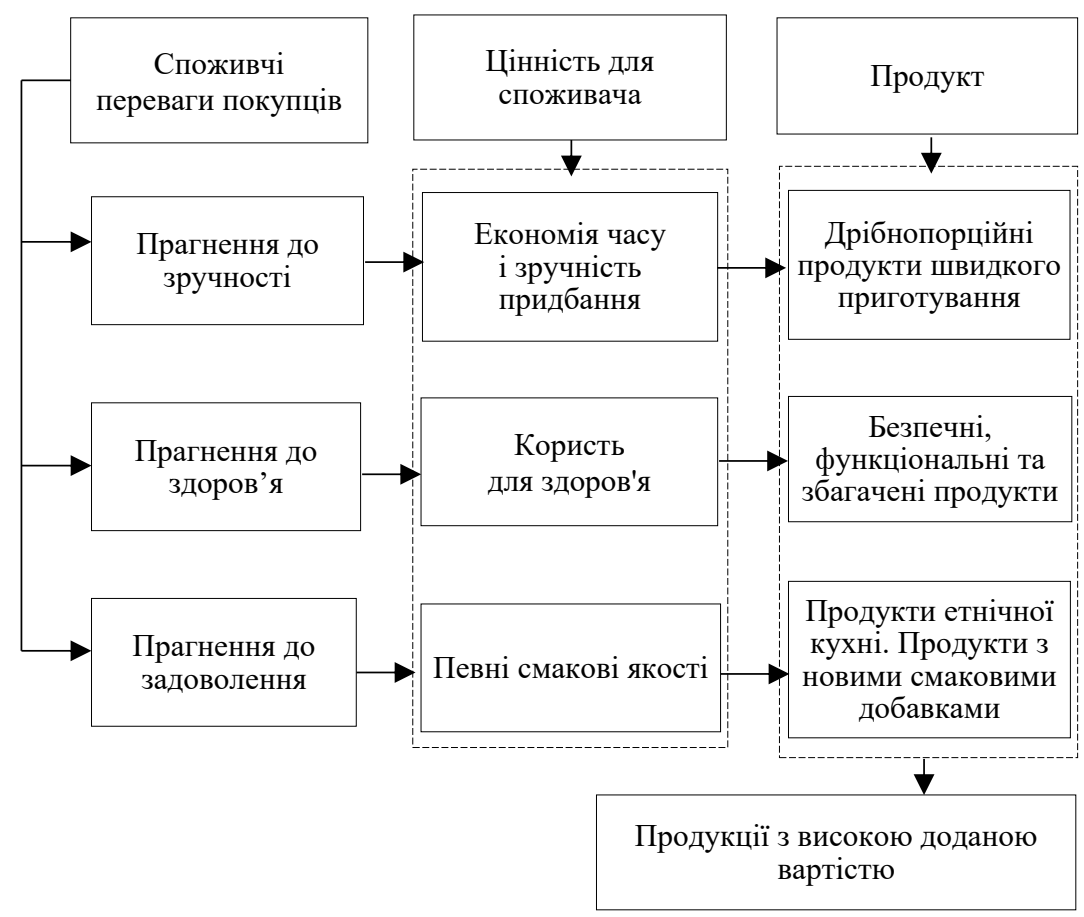

\section{Рис. 2. Споживчі переваги покупців в продуктах харчування}

Важливою передумовою формування ефективних ланцюгів створення вартості продукту в харчовій промисловості $\epsilon$ визначення потреб покупців і виявлення операцій, які ведуть до задоволення цих потреб, створюючи додану цінність або сприяючи ii створенню. Велика увага в харчовій галузі приділяється поліпшенню якості та розширенню асортименту виробленої продукції, впровадженню інноваційних технологій, освоєнню новітніх методів і видів упаковки.

Сучасне економічне сьогодення характеризується нестабільним, швидко змінюваним, динамічним, практично не контрольованим зовнішнім середовищем, в яке залучені всі суб'єкти господарської діяльності. Здійснюючи в таких умовах формування «нового» або оцінку ефективності вже існуючого 
ланцюга створення вартості продукту важливим є встановлення зовнішніх і внутрішніх факторів, що впливають на неї.

На рис. 3 представлені зовнішні і внутрішні фактори, що впливають на ефективність функціонування ланцюга створення вартості в харчовій промисловості [4; 5].

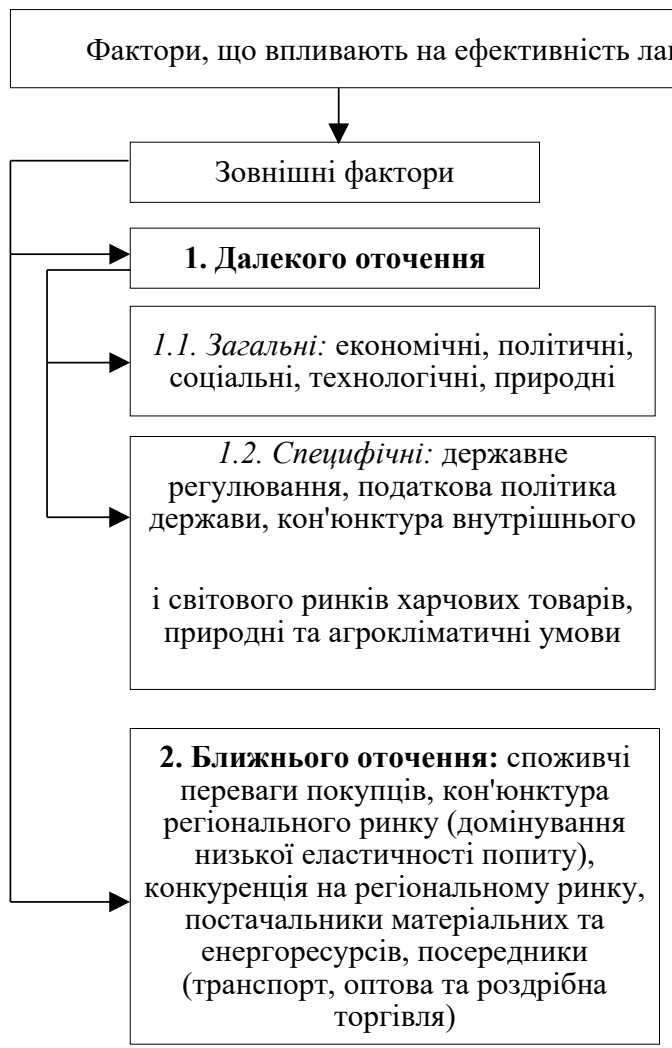

ццга створення вартості

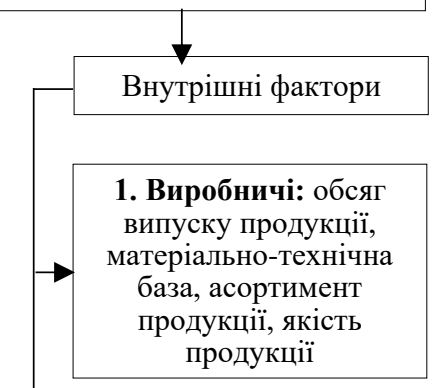

2. Кадрові: якісний склад кадрів, продуктивність праці, система оплати праці

\section{3. Інноваційно-}

технологічні: технологія виробництва, інвестиції в основний капітал, витрати на технологічні інновації

\section{Рис. 3. Фактори, що впливають на ефективність ланцюга створення вартості в харчовій промисловості}

Таким чином, встановлено сукупність специфічних факторів, що впливають на ефективність ланцюга створення вартості в харчовій промисловості. 
Зміна споживчих переваг покупців $є$ не менш важливим фактором, який впливає на ланцюг виробництва в харчовій промисловості. У деяких випадках вплив цього чинника може призвести до припинення функціонування ланцюга створення вартості окремих видів харчових товарів.

Отже, харчова промисловість є стратегічно значущою галуззю, яка і на яку впливають и працюють майже всі галузі народного господарства, а також $\epsilon$ найважливішою передумовою для подолання кризових явищ та досягнення сталого розвитку.

\section{Література:}

1. Дейнеко Л.В., Шелудько Е.І. Харчова промисловість України: ефективність використання виробничих ресурсів і кадрового потенціалу. Київ : НАН України, ДУ «Ін-т екон. та прогноз.», 2013. 120 с.

2. Сервіс для визначення кодів видів економічної діяльності за КВЕД-2005 та КВЕД-2010. URL: http://kved.ukrstat.gov.ua/KVED2010/10/KVED 10_10.html.

3. Сичевський М.П. Харчова промисловість як основа продовольчої безпеки та розвитку держави. Київ : Аграр. наука, 2019. 388 с.

4. Інвестиційна активність підприємств з виробництва продукції з високою доданою вартістю в умовах обмежених ринків: парадигма та механізми забезпечення: монографія / Н.Ю. Брюховецька, І.П. Булєєв та ін. Київ : НАН України, Ін-т економіки пром-сті, 2019. 388 с.

5. Купчак П.М. Харчова промисловість України в умовах активізації інтеграційних та глобалізаційних процесів: монографія / за ред. доктора економічних наук, професора Л.В. Дейнеко. Київ : Рада по вивч. прод. сил України НАН України, 2009. 152 с. 